\title{
Effect of incubation conditions, inhibitors and seminal plasma on protein synthesis in ram spermatozoa*
}

\author{
N. A. Ahmed $\uparrow$, M. H. Salem $\ddagger$, H. A. El-Oksh $\dagger$ and V. G. Pursel§ \\ †Department of Animal Production, Faculty of Agriculture, Al-Azhar University, Cairo, Egypt ; \\ $\ddagger$ Unit of Molecular Biology, University of Alexandria Research Center (UNARC), Alexandria, \\ Egypt; and §Reproduction Laboratory, U.S. Department of Agriculture, Beltsville, \\ Maryland 20705, U.S.A.
}

\begin{abstract}
Summary. The effects of incubation time ( $15 \mathrm{~min}-4 \mathrm{~h})$, rate of semen to buffer dilution $(1 / 10-1 / 40)$, and concentration of glucose $(5 \cdot 5-22 \mathrm{mM})$ on the rate of protein synthesis by ejaculated washed ram spermatozoa were determined. The rate of protein synthesis increased linearly as incubation time, dilution rate, and the glucose concentration increased. Denaturation of sperm protein with $1 \% \mathrm{HgCl}_{2}$ caused an almost complete inhibition of amino acid incorporation. Protein synthesis over a period of $4 \mathrm{~h}$ was also inhibited by chloramphenicol but was not affected by cycloheximide. Protein synthesis and uptake of $\left[{ }^{14} \mathrm{C}\right] \mathrm{cAMP}$ by washed ram spermatozoa was also significantly inhibited by the inclusion of $2-8 \%$ seminal plasma in the buffer. The present results indicate that the authentic protein synthesis by mature ram spermatozoa is mainly of mitochondrial origin. The data also suggest a role for intracellular cAMP in the regulation of sperm protein synthetic activity.
\end{abstract}

\section{Introduction}

Mature bull, human and mouse spermatozoa synthesize protein at a significant rate in vitro (Premkumar \& Bhargava, 1972; Mujica, 1976; Bragg \& Handel, 1979). Experiments utilizing protein inhibitors indicated that these newly synthesized proteins are of mitochondrial origin. The in-vitro rate of sperm protein synthesis, however, seems to be greatly influenced by incubation conditions. Using a short incubation period, Busby, Hele \& Chang (1974) failed to show authentic protein synthesis by rabbit spermatozoa. In addition, Bhargava (1957) and Bhargava, Bishop \& Work (1959) found that the rate of amino acid incorporation into protein was low and stopped abruptly after $20 \mathrm{~min}$ in whole bovine semen, whereas in washed spermatozoa it continued at a constant rate for several hours. This latter observation was explained by an inhibitory effect of seminal plasma on sperm RNA and protein synthesis (Bhargava et al., 1959; Abraham \& Bhargava, 1963b) that was thought to be due to the presence in bovine seminal plasma of large amounts of active ribonuclease (Abraham \& Bhargava, 1963a; Premkumar \& Bhargava, 1972). Another point to consider is that the dilution of washed spermatozoa with the ionic components of the buffer (in contrast to the whole semen) could be associated with an increase in the intracellular cyclic AMP (cAMP) level with a concomitant enhancement of sperm activity (Kopf \& Garbers, 1978; Turner \& Howards, 1978). The increased sperm activity results in a large demand for energy

* Reprint requests to Dr V. G. Pursel.

(C) 1984 Journals of Reproduction \& Fertility Ltd 
that is met by greater consumption of glucose (Hoskins \& Casillas, 1974; Cascieri, Amann \& Hammerstedt, 1976).

The objective of the present study was to investigate the influence of incubation conditions on the in-vitro rate of protein synthesis by ejaculated ram spermatozoa.

\section{Materials and Methods}

Semen collection and handling. Semen samples were obtained from 6 Ossimi rams, 2-3 years of age. One or two ejaculates were collected from each ram twice per week by means of an artificial vagina. To avoid sudden temperature changes, the individual tubes containing the semen samples were maintained in a vacuum flask at $37^{\circ} \mathrm{C}$ until used. The individual ejaculates of semen were examined immediately after collection for ejaculate volume, colour, opacity, initial pH, epithelial cells, and mass motility (Perry, 1960). Only ejaculates with a volume in the normal range (about $1 \mathrm{ml}$ ), white in colour, opaque, $\mathrm{pH}$ of about 6.9 , free of epithelial cells, and mass motility of not less than 4 (on a scale of 0 to 5) were used. Selected ejaculates were pooled within $30 \mathrm{~min}$ after collection and used in the subsequent experiments. Sperm concentration was determined on pooled semen samples with a haemocytometer as described by Herman \& Madden (1953).

Protein synthesis by washed spermatozoa. Semen samples from 4-6 rams were pooled after the initial examination. Spermatozoa were quickly separated from seminal plasma by centrifugation at $1000 \mathrm{~g}$ for $5 \mathrm{~min}$, and were washed twice in buffer containing $42 \mathrm{mM}-\mathrm{KCl}, 103 \mathrm{~mm}-\mathrm{NaCl}, 5 \mathrm{~mm}-$ $\mathrm{MgSO}_{4} \cdot 7 \mathrm{H}_{2} \mathrm{O}, 10 \mathrm{~mm}-\mathrm{KH}_{2} \mathrm{PO}_{4}$ and $10 \mathrm{~mm}-\mathrm{Tris}-\mathrm{HCl}$ at $\mathrm{pH} 7 \cdot 2$ (Hoskins, Hall \& Munsterman, 1975). After washing, the spermatozoa were resuspended and diluted in the same buffer to which $100 \mu \mathrm{g}$ penicillin- $\mathrm{G} / \mathrm{ml}$ was added. Unless otherwise specified, the dilution ratio was $1: 40$ (original semen volume : final volume) and the buffer contained $22 \mathrm{~mm}$-glucose. Thoroughly mixed sperm suspensions were divided into appropriate volumes, to which the desired concentrations of the tested compounds were added, and then distributed in the incubation tubes at $2 \mathrm{ml} / \mathrm{tube}$. $\left[{ }^{3} \mathrm{H}\right]$ Leucine (L-[3,4,5- $\left.{ }^{3} \mathrm{H}(\mathrm{N})\right]$ leucine, sp. act. $145 \mathrm{Ci} / \mathrm{mmol}$; New England Nuclear, Boston, MA) was added $(5 \mu \mathrm{Ci})$ to each tube, and the tubes were incubated for designated times at $37^{\circ} \mathrm{C}$. Seminal plasma, used as an additive in some incubations, was obtained by centrifugation of $6-8 \mathrm{ml}$ pooled semen at $1000 \mathrm{~g}$ for $10 \mathrm{~min}$. The plasma was then stored at $-20^{\circ} \mathrm{C}$ until used.

Precautions used to prevent bacterial contamination included sterilization of glassware and solutions. In each experiment a control sample of washed spermatozoa was microscopically examined at hourly intervals throughout the 4-h incubation period to check for bacterial contamination and assess progressive sperm motility. If bacteria were present or the progressive sperm motility declined abnormally, the experiment was stopped and subsequent extraction procedures were not completed.

At the end of incubation, incorporation of $\left[{ }^{3} \mathrm{H}\right]$ leucine was terminated by adding $2 \mathrm{ml}$ buffer containing $10 \mathrm{~mm}$ non-radioactive $\mathrm{L}$-leucine to each tube and centrifuging at $1000 \mathrm{~g}$ for $10 \mathrm{~min}$. The sperm pellet was then resuspended in $10 \mathrm{mM}$-L-leucine buffer in a final volume of $0.6 \mathrm{ml}$ and the radioactive proteins were solubilized according to the method of Hernandez-Montes, Iglesias \& Mujica (1973). A freshly prepared solution of $9 \mathrm{mM}$ dithiothreitol in $0.05 \mathrm{M}$ Tris-buffer ( $\mathrm{pH} \mathrm{8.0)}(0.2$ $\mathrm{ml}$ ) was mixed with the $0.6 \mathrm{ml}$ sperm suspension and allowed to stand for $15 \mathrm{~min}$. At the end of this period, $0.2 \mathrm{ml} 30 \%(\mathrm{w} / \mathrm{v}) \mathrm{NaOH}$ was added and the mixture was allowed to stand for an additional $15 \mathrm{~min}$. All procedures were carried out at room temperature. After solubilization, the radioactive proteins were extracted by a modification of the procedure of Seikevitz (1952). The proteins were precipitated twice from the digested material by an equal volume of $10 \%$ trichloroacetic acid (TCA) and centrifuged at $1000 \mathrm{~g}$ for $10 \mathrm{~min}$. A 3-ml mixture of $\mathrm{L}$-leucine and TCA $(1: 1, \mathrm{v}: \mathrm{v})$ was added to the TCA-insoluble precipitate, heated for $15 \mathrm{~min}$ at $70-80^{\circ} \mathrm{C}$ and centrifuged. The precipitate was then washed twice with $3 \mathrm{ml} 0.1 \mathrm{M}$ potassium acetate in ethanol, twice with a mixture of ethanol- 
ether $(2: 1, \mathrm{v}: \mathrm{v})$ and twice with absolute ether. Ether was evaporated leaving an odourless white powder. The dried TCA-precipitable proteins were dissolved in $3 \mathrm{ml} 1 \mathrm{~N}-\mathrm{NaOH}$. One aliquot was used for radioactive measurements in methyl cellosolve scintillation solution (Trewava, 1967), and duplicate aliquots were used for protein determination by the method of Lowry, Rosebrough, Farr \& Randall (1951), using bovine serum albumin as a standard. Specific activity was expressed as c.p.m. $\left[{ }^{3} \mathrm{H}\right]$ leucine incorporated/mg protein.

Cyclic AMP accumulation. Reaction mixtures were prepared by resuspending $5 \times 10^{7}$ washed ram spermatozoa in $2 \mathrm{ml}$ buffer (Hoskins et al., 1975) or buffer containing 4\% seminal plasma. Also, $0 \cdot 125 \mu \mathrm{Ci}$ of cyclic $\left[{ }^{14} \mathrm{C}\right] \mathrm{AMP}$ (sp. act. $80 \mathrm{mCi} / \mathrm{mmol}$; New England Nuclear) was added to each tube, and incubated for $4 \mathrm{~h}$ at $37^{\circ} \mathrm{C}$. After incubation, spermatozoa were sonicated for three 30 -sec periods interspaced with $2-$ min periods of cooling in a melting ice bath. Spermatozoa were then homogenized for $2 \mathrm{~min}$ in a glass Potter-Elvehjem homogenizer, cooled for $10 \mathrm{~min}$ in an ice bath, and free and cell-bound cAMP were separated by filtering the homogenate with a Millipore filtration apparatus using a $\mathbf{0 . 4 5} \mu \mathrm{m}$ membrane (Rosado, Huacuja, Delgado, Hicks \& Pancardo, 1976). Specific activity of the bound cAMP was expressed as c.p.m. $\left[{ }^{14} \mathrm{C}\right] \mathrm{cAMP} / \mathrm{mg}$ protein.

Statistical analysis. The statistical analyses were carried out according to Snedecor \& Cochran (1973). One way analysis of variance and $t$ tests were carried out to test the significance of difference between groups. With the exception of data presented in Table 1, experiments were repeated 2 or 3 times. Each one was analysed separately, then similar replicates were pooled for final analysis.

\section{Results}

\section{Optimal incubation conditions}

Washed spermatozoa were diluted to $1 / 10,1 / 20$ and $1 / 40$ (original semen volume : final volume) in buffer that contained $22 \mathrm{~mm}$-glucose, and $100 \mu \mathrm{g}$ penicillin- $\mathrm{G} / \mathrm{ml}$, and were incubated at $37^{\circ} \mathrm{C}$ for $0.25,0.5,1,2$ and $4 \mathrm{~h}$. The results in Text-fig. 1 indicate that the incorporation of $\left[{ }^{3} \mathrm{H}\right] l$ leucine into TCA-insoluble proteins was a time-dependent phenomenon. The rate of protein synthesis was maximal at $1 / 40$ dilution $\left(5-8 \times 10^{7}\right.$ spermatozoa/ml) and during incubation for $4 \mathrm{~h}$ increased linearly, i.e. time curve concave upward due to $\log$ scale. The rate of leucine incorporation was increased further at 1/80 dilution but results showed higher variability. Accordingly, the 1/40 dilution was used in all subsequent studies. The rate of protein synthesis was also measured after $4 \mathrm{~h}$ of incubation in buffer containing $5 \cdot 5,11$ or $22 \mathrm{~mm}$-glucose. The rate of $\left[{ }^{3} \mathrm{H}\right]$ leucine incorporation increased linearly $(P<0.05)$ up to $22 \mathrm{~mm}$-glucose (Table 1$)$.

Table 1. Effect of glucose concentration on incorporation of $\left[{ }^{3} \mathrm{H}\right]$ leucine by washed ram spermatozoa during incubation for $4 \mathrm{~h}$ at $37^{\circ} \mathrm{C}$

\begin{tabular}{ccc}
\hline $\begin{array}{c}\text { Glucose conc. } \\
\text { (mM) }\end{array}$ & $\begin{array}{c}\text { No. of } \\
\text { observations }\end{array}$ & $\begin{array}{c}\text { Mean } \pm \text { s.e.m. } \\
\text { specific activity } \\
\text { (c.p.m./mg protein) }\end{array}$ \\
\hline $5 \cdot 5$ & 5 & $8451 \pm 915^{\mathrm{a}}$ \\
11 & 8 & $10272 \pm 1056^{\mathrm{ab}}$ \\
22 & 6 & $13150 \pm 422^{\mathrm{b}}$ \\
\hline
\end{tabular}

Means with different superscript letters differ significantly $(P<0.05)$. 


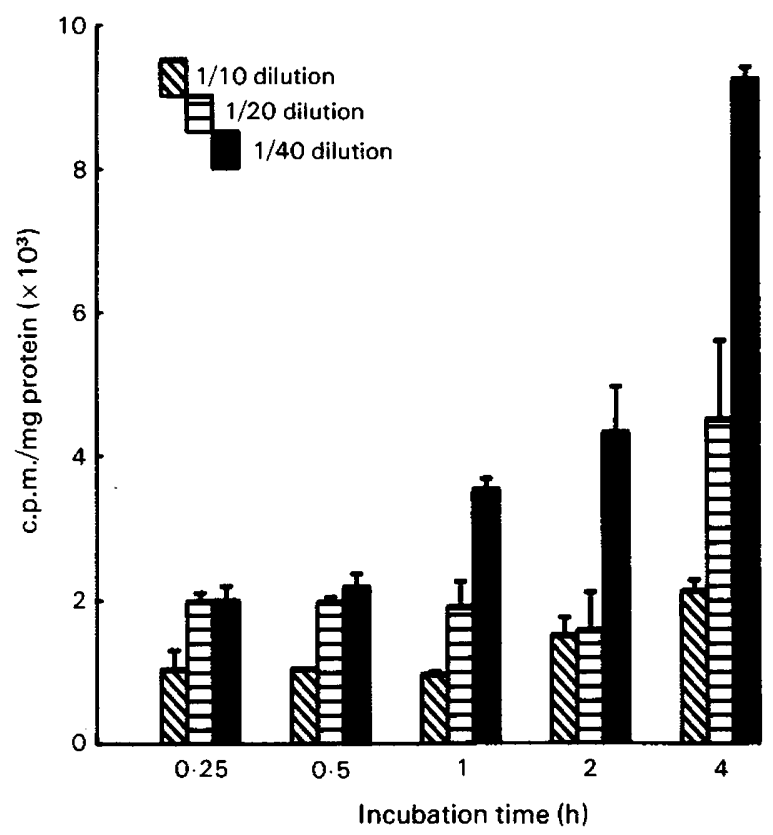

Text-fig. 1. Incorporation of $\left[{ }^{3} \mathrm{H}\right]$ leucine into TCA-precipitable protein by washed ram spermatozoa incubated at $37^{\circ} \mathrm{C}$ for different times at 3 dilution rates. Values are mean \pm s.e.m.

For the incubation variables presently studied the optimal conditions for the in-vitro protein synthesis by ram spermatozoa were reached during a 4-h incubation period at $37^{\circ} \mathrm{C}$, and when washed spermatozoa were diluted to $1 / 40$ with incubation buffer that contained $100 \mu \mathrm{g}$ pencillin$\mathrm{G} / \mathrm{ml}$ and 22 mM-glucose.

\section{Effect of inhibitors}

Table 2 shows the results obtained when different inhibitors of protein synthesis were added to the incubation media. Denaturation of the sperm protein with $1 \% \mathrm{HgCl}_{2}$ caused an almost complete inhibition of protein synthesis. Incubation of spermatozoa in the presence of 50,100 or $200 \mathrm{~g}$ chloramphenicol $/ \mathrm{ml}$ (an inhibitor of mitochondrial protein synthesis at the translational level) caused a significant $(P<0.001)$ inhibition of amino acid incorporation by $72-86 \%$. No significant effect was observed, however, when equivalent doses of the cytoplasmic inhibitor, cycloheximide, were used. Additionally, a dose of $100 \mu \mathrm{g}$ cycloheximide $/ \mathrm{ml}$ did not potentiate the inhibitory effect of a similar dose of chloramphenicol.

\section{Effect of seminal plasma}

Washed ram spermatozoa were also incubated in buffer containing graded doses of seminal plasma. The results in Table 3 showed a consistent inhibition of protein synthesis by this treatment. Regression analysis indicated a linear inhibition $(P<0.01)$ of protein synthesis over the 3 doses of seminal plasma used. This inhibitory role of seminal plasma on protein synthesis could be due to its inhibitory effect on endogenous cAMP levels. Spermatozoa incubated for $4 \mathrm{~h}$ in buffer containing $4 \%$ seminal plasma accumulated only $36 \%$ as much $\left[{ }^{14} \mathrm{C}\right] \mathrm{cAMP}$ as did spermatozoa incubated in control buffer ( $7065 \pm 689$ compared with $19806 \pm 3170 \mathrm{cpm} / \mathrm{mg}$ protein, respectively, $P<0.05$ ). 
Table 2. Effect of $\mathrm{HgCl}_{2}$, chloramphenicol and cycloheximide on incorporation of $\left[{ }^{3} \mathrm{H}\right]$ leucine by washed ram spermatozoa during incubation for $4 \mathrm{~h}$ at $37^{\circ} \mathrm{C}$

\begin{tabular}{|c|c|c|c|}
\hline \multirow[b]{2}{*}{ Treatment } & \multirow[b]{2}{*}{$\begin{array}{c}\text { No. of } \\
\text { observations* }\end{array}$} & \multicolumn{2}{|c|}{ Specific activity (c.p.m./mg protein) } \\
\hline & & Mean \pm s.e.m. & $\begin{array}{c}\text { Deviation } \\
\text { from control }(\%)\end{array}$ \\
\hline Control & 10 & $20828 \pm 1193^{a}$ & - \\
\hline $\mathrm{HgCl}_{2}(1 \%)$ & 6 & $916 \pm 347^{c}$ & -96 \\
\hline \multicolumn{4}{|c|}{ Chloramphenicol } \\
\hline $50 \mu \mathrm{g} / \mathrm{ml}$ & 7 & $5747 \pm 1107^{b}$ & -72 \\
\hline $100 \mu \mathrm{g} / \mathrm{ml}$ & 7 & $3542 \pm 272^{b}$ & -83 \\
\hline $200 \mu \mathrm{g} / \mathrm{ml}$ & 7 & $2878 \pm 330^{\mathrm{b}}$ & -86 \\
\hline \multicolumn{4}{|l|}{ Cycloheximide } \\
\hline $50 \mu \mathrm{g} / \mathrm{ml}$ & 9 & $20473 \pm 2794^{a}$ & -2 \\
\hline $100 \mu \mathrm{g} / \mathrm{ml}$ & 7 & $18664 \pm 1048^{\mathrm{a}}$ & -10 \\
\hline $200 \mu \mathrm{g} / \mathrm{ml}$ & 9 & $22547 \pm 805^{a}$ & +8 \\
\hline \multicolumn{4}{|c|}{$\begin{array}{l}\text { Chloramphenicol } \\
(100 \mu \mathrm{g} / \mathrm{ml})\end{array}$} \\
\hline \multicolumn{4}{|c|}{$\begin{array}{c}+ \\
+\end{array}$} \\
\hline$(100 \mu \mathrm{g} / \mathrm{ml})$ & 7 & $2393 \pm 162^{b}$ & -89 \\
\hline
\end{tabular}

* Obtained in two experiments.

Means with different superscript letters differ significantly $(P<0.001)$.

Table 3. Effect of adding seminal plasma on the incorporation of $\left[{ }^{3} \mathrm{H}\right] l$ leucine by washed ram spermatozoa after incubation for $4 \mathrm{~h}$ at $37^{\circ} \mathrm{C}$

\begin{tabular}{lccc}
\hline & \multicolumn{2}{c}{ Specific activity (c.p.m./mg protein) } \\
\cline { 3 - 4 } \multicolumn{1}{c}{$\begin{array}{c}\text { No. of } \\
\text { Treatment }\end{array}$} & observations* & Mean \pm s.e.m. & $\begin{array}{c}\text { Deviation } \\
\text { from control (\%) }\end{array}$ \\
\hline Control & 17 & $20527 \pm 2413^{\mathrm{a}}$ & - \\
Seminal plasma & 12 & $15284 \pm 1794^{\mathrm{b}}$ & -26 \\
$2 \%$ & 13 & $9773 \pm 463^{\mathrm{c}}$ & -52 \\
$4 \%$ & 13 & $5272 \pm 339^{\mathrm{d}}$ & -74 \\
$8 \%$ & & & \\
\hline
\end{tabular}

* Obtained in 3 experiments.

Means with different superscript letters differ significantly $(P<0.005)$.

\section{Discussion}

The present studies demonstrated that serial dilutions of washed ram spermatozoa increased the rate of protein synthesis (Text-fig. 1). The rate of protein synthesis at the 1:40 sperm-buffer dilution was linear over a period of $4 \mathrm{~h}$ at $37^{\circ} \mathrm{C}$. This increase in protein synthesis may be related to the increase in endogenous cAMP that also occurs during dilution. Kopf \& Garbers (1978) found that a 1.6- to 52-fold increase in dilution of washed sea-urchin spermatozoa with sea water caused a substantial increase in levels of sperm cAMP and respiration rate. Cascieri et al. (1976) found that dilution of bull epididymal spermatozoa with cauda epididymal plasma had the same effect as a buffer solution or accessory sex gland fluid in stimulation of adenylate cyclase and initiation of progressive motility. The latter was preceded by a rise in endogenous cAMP and a decrease in ATP. The mechanism by which dilution induces these metabolic and functional changes is poorly understood. Perhaps an inhibitory factor is present on spermatozoa that is not removed by 
washing. As the dilution rate increases, the inhibitory factor becomes dissociated from the spermatozoa, permitting the stimulation of metabolism and protein synthesis to follow as a consequence.

The present study also showed that the dose of exogenous glucose substrate (up to $20 \mathrm{mM}$ ) was positively correlated with leucine incorporation by ram spermatozoa during incubation for $4 \mathrm{~h}$. Possibly the increase in protein synthesis after dilution creates a demand for energy that can be met by increased metabolism of glucose.

The authenticity of protein synthesis by washed ram spermatozoa is supported by studies involving the use of inhibitors of protein synthesis (Table 2). Denaturation of sperm protein with $1 \% \mathrm{HgCl}_{2}$ caused an almost complete inhibition of $\left[{ }^{3} \mathrm{H}\right]$ leucine incorporation. Protein synthesis over a period of $4 \mathrm{~h}$ was also inhibited by chloramphenicol but was not inhibited by cycloheximide, indicating that the newly synthesized protein is of mitochondrial origin.

In direct contrast to these results, Busby et al. (1974) found that ejaculated rabbit spermatozoa only incorporated a low level of amino acids into TCA-insoluble material and inhibitors of protein synthesis failed to prevent amino acid incorporation. Busby et al. (1974) also reported that denatured rabbit sperm proteins incorporated about $50 \%$ as much radioactive amino acid as the living spermatozoa. They concluded that amino acids or their metabolites were physically sequestered by the sperm proteins. However, the short period of incubation $(40 \mathrm{~min})$ and high sperm concentration $\left(2 \times 10^{8} / \mathrm{ml}\right)$ used for rabbit spermatozoa differed markedly from the conditions in our study and that of Bragg \& Handel (1979); the differences in incubation conditions may explain the different results with rabbit spermatozoa. The present results, however, confirm previous observations on other species. Premkumar \& Bhargava (1972) reported that protein synthesis in bull spermatozoa was inhibited by chloramphenicol but not by cycloheximide. Similar results were found for human (Mujica, 1976) and mouse (Bragg \& Handel, 1979) spermatozoa. Premkumar \& Bhargava (1972) also observed that protein synthesis by bull spermatozoa depends on continued RNA synthesis, and probably involves a short-lived messenger. Studies by Fuster, Farrell, Stern \& Hecht (1977) and by Hecht \& Williams $(1978,1979)$ also suggested that much of the RNA synthesis observed in bull spermatozoa is mitochondrial in origin.

In the present study, addition of seminal plasma to the incubation buffer markedly inhibited both protein synthesis (Table 3 ) and the binding of $\left[{ }^{14} \mathrm{C}\right] \mathrm{CAMP}$ by washed ram spermatozoa. The inhibitory effect of seminal plasma on protein synthesis may be due to its alteration of endogenous sperm cAMP. This possibility is supported by results in which exogenous addition of cAMP or phosphodiesterase inhibitors to washed ram spermatozoa stimulated the rate of protein synthesis (M. H. Salem, unpublished results). Tash (1976) found that ram seminal plasma contains three isoenzymes of phosphodiesterase, so metabolism of $\left[{ }^{14} \mathrm{C}\right] \mathrm{cAMP}$ by phosphodiesterase contained in the seminal plasma is a possible consequence. Previous studies with bull spermatozoa demonstrated that seminal plasma had an inhibitory effect on both RNA and protein synthesis (Bhargava et al., 1959; Abraham \& Bhargava, 1963b); the inhibition was attributed to the presence of large amounts of active ribonuclease in seminal plasma (Abraham \& Bhargava, 1963a; Premkumar \& Bhargava, 1972). A protein called seminalplasmin has been isolated from bovine seminal plasma and Reddy \& Bhargava (1979) suggest that this is responsible for the inhibition of protein and RNA synthesis by spermatozoa.

Another possibility, which has not been discounted, is that free amino acids contained in seminal plasma (Setchell, Hinks, Voglmayr \& Scott, 1967) might dilute the $\left[{ }^{3} \mathrm{H}\right] l e u c i n e ~ s p e c i f i c$ activity and result in the appearance of inhibition of protein synthesis.

In conclusion, the results of the present study indicate that the mitochondria of ram spermatozoa synthesize protein during in-vitro incubation at $37^{\circ} \mathrm{C}$. The degree of sperm dilution, concentration of exogenous glucose, and presence of seminal plasma markedly affect the rate of protein synthesis. The question of what physiological role these newly synthesized proteins play in spermatozoa remains to be answered. The possible involvement of endogenous cAMP with protein synthesis is being investigated. 
This research was supported by USDA PL-480 Project No. EG-ARS-34 Grant No. FG-EG155.

\section{References}

Abraham, K.A. \& Bhargava, P.M. (1963a) Nucleic acid metabolism of mammalian spermatozoa. Biochem. $J$. 86, 298-307.

Abraham, K.A. \& Bhargava, P.M. (1963b) The uptake of radioactive amino acids by spermatozoa, the intracellular site of incorporation into proteins. Biochem. $J$. 86, 308-313.

Bhargava, P.M. (1957) Incorporation of radioactive amino acids in the protein of bull spermatozoa. Nature, Lond. 179, 1120-1121.

Bhargava, P.M., Bishop, M.W.H. \& Work, T.S. (1959) Incorporation of ${ }^{14} \mathrm{C}$-amino acids into the proteins of bull spermatozoa. Biochem. J. 73, 247-256.

Bragg, P.W. \& Handel, M.A. (1979) Protein synthesis in mouse spermatozoa. Biol. Reprod. 20, 333-337.

Busby, W.R., Hele, P. \& Chang, M.C. (1974) Apparent amino acid incorporation by ejaculated rabbit spermatozoa. Biochem. Biophys. Acta 330, 246-259.

Cascieri, M., Amann, R.P. \& Hammerstedt, R.H. (1976) Adenine nucleotide changes at initiation of bull sperm motility. J. biol. Chem. 251, 787-793.

Fuster, C.D., Farrell, D., Stern, F.A. \& Hecht, N.B. (1977) RNA polymerase activity in bovine spermatozoa. $J$. Cell Biol. 74, 698-706.

Hecht, N.B. \& Williams, J.L. (1978) Synthesis of RNA by separated heads and tails from bovine spermatozoa. Biol. Reprod. 19, 573-579.

Hecht, N.B. \& Williams, J.L. (1979) Nuclear and mitochondrial DNA-dependent RNA polymerases in bovine spermatozoa. J. Reprod. Fert. 57, 157-165.

Herman, H.A. \& Madden, F.W. (1953) The Artificial Insemination of Dairy Cattle. Lucas Brothers Publishers, Colombia, Missouri.

Hernandez-Montes, H., Iglesias, G. \& Mujica, A. (1973) Selective solubilization of mammalian spermatozoa structures. Expl Cell Res. 76, 437-440.

Hoskins, D.D. \& Casillas, E.R. (1974) Hormones, second messengers and the mammalian spermatozoon. In Advances in Sex Hormone Research, Vol. 1, pp. 283324. Eds R. L. Singhal \& J. A. Thomas. University Park Press, Baltimore.

Hoskins, D.D., Hall, M.L. \& Munsterman, D. (1975) Induction of motility in immature bovine spermatozoa by cyclic AMP phosphodiesterase inhibitors and seminal plasma. Biol. Reprod. 13, 168-176.
Kopf, G.S. \& Garbers, D.L. (1978) Correlation between sea urchin sperm respiratory rates and cyclic AMP concentrations as a function of cell dilution. Biol. Reprod. 18, 229-233.

Lowry, O.H., Rosebrough, N.J., Farr, A.L. \& Randall, R.J. (1951) Protein measurement with the Folin phenol reagent. J. biol. Chem. 193, 265-275.

Mujica, A. (1976) Mitochondrial protein synthesis in human ejaculated spermatozoa. $J$. Cell Biol. 70, 416a, Abstr.

Perry, E.J. (1960) The Artificial Insemination of Farm Animals, 3rd edn. Rutgers University Press, New Brunswick.

Premkumar, F. \& Bhargava, P.M. (1972) Transcription and translation in bovine spermatozoa. Nature, New Biol. 240, 139-143.

Reddy, E.S.P. \& Bhargava, P.M. (1979) Seminaplasmin. An antimicrobial protein from bovine seminal plasma which acts in $E$. coli by specific inibition of r-RNA synthesis. Nature, Lond. 279, 725-728.

Rosado, A., Huacuja, L., Delgado, N.M., Hicks, J.J. \& Pancardo, R.M. (1976) Cyclic AMP receptors in the human spermatozoa membrane. Life Sci. 17, 17071714.

Seikevitz, P. (1952) Uptake of radioactive alanine in vitro into the proteins of rat liver fractions. J. biol. Chem. 195, 549-565.

Setchell, B.P., Hinks, N.T., Voglmayr, J.K. \& Scott, T.W. (1967) Amino acids in ram testicular fluid and semen and their metabolism by spermatozoa. Biochem. J. 105, 1061-1065.

Snedecor, G.W. \& Cochran, W.G. (1973) Statistical Methods, 6th edn. Iowa State University Press, Ames.

Tash, J.S. (1976) Investigations on adenosine 3',5'-monophosphate phosphodiesterase in ram semen and initial characterization of a sperm-specific isoenzyme. J. Reprod. Fert. 47, 63-72.

Trewava, A.A. (1967) A new method for liquid scintillation. Analyt. Biochem. 21, 324-329.

Tumer, T.T. \& Howards, S.S. (1978) Factors involved in the initiation of sperm motility. Biol. Reprod. 18, 571578.

Received 15 November 1983 